\title{
The relationship between optimism-pessimism, loneliness, and death anxiety
}

\author{
STEPHEN F. DAVIS, KAIRA M. MILLER, DONNA JOHNSON, \\ KAMERON MCAULEY, and DEANNA DINGES \\ Emporia State University, Emporia, Kansas
}

\begin{abstract}
Two hundred sixty undergraduate college students ( 167 women, 93 men) served in a study to ascertain the relationships among loneliness, optimism, pessimism, and death anxiety. Corroborating previous data, the results indicated that loneliness was positively related to pessimism but negatively related to optimism. Optimism and pessimism were negatively related. Contrary to initial predictions, death anxiety was not consistently related to the other factors.
\end{abstract}

The development of the Revised UCLA Loneliness Scale (Russell, Peplau, \& Cutrona, 1980) and general interest in the topic of loneliness have led to increased research activity in this area. For example, Davis, Hanson, Edson, and Ziegler (in press) reported data pertaining to the relationship of loneliness, optimism, pessimism, and self-esteem.

The results of the Davis et al. (in press) study indicated that loneliness and optimism were inversely related, whereas loneliness and pessimism were positively related. Optimism and pessimism were shown to be inversely related. Finally, the results of this study established a relationship between loneliness and self-esteem and between optimism-pessimism and self-esteem. Loneliness and selfesteem and pessimism and self-esteem were negatively related, whereas optimism and self-esteem were positively related.

In light of the Davis et al. (in press) data, the strong negative relationship between self-esteem and death anxiety reported by Buzzanga, Miller, Perne, Sander, and Davis (1989) suggests that loneliness and pessimism should be positively related with death anxiety. Conversely, it is predicted that death anxiety and pessimism should be positively related. Finally, death anxiety and loneliness should be positively related.

The present experiment was designed to evaluate these predicted relationships. A secondary purpose was to replicate both the negative relationship between loneliness and optimism and the negative relationship between optimism and pessimism reported by Davis et al. (in press).

\section{METHOD}

\section{Subjects}

Two hundred sixty undergraduate college students (167 women, 93 men) enrolled in introductory psychology classes at a regional, midwestern state university volunteered to serve as subjects.

Correspondence should be addressed to Stephen F. Davis, Department of Psychology, Emporia State University, 1200 Commercial, Emporia, KS 66801-5087.

\section{Testing Instruments}

The Revised UCLA Loneliness Scale (Russell et al., 1980), the Optimism-Pessimism Scale (Dember, Martin, Hummer, Howe, \& Melton, 1989), and the Death Anxiety Scale (DAS; Templer, 1970) were combined into a self-administering questionnaire booklet. The Revised UCLA Loneliness Scale is a 20-item scale that correlates significantly with scores on the Beck Depression Inventory and the Costello-Comrey Anxiety and Depression Scale (Russell et al., 1980).

The Dember et al. (1989) Optimism-Pessimism Scale consists of 56 items to which subjects indicate their degree of agreement. Eighteen of the items form an optimism scale; another 18 items form a pessimism scale. Twenty items serve as fillers. Thus, separate optimism and pessimism scores are produced by the instrument. Dember and Brooks (1989) reported that the test-retest reliability for the optimism scale was .75 , whereas the test-retest reliability of the pessimism scale was .84 . Additionally, these scales were shown to be significantly related to measures of happiness.

The DAS consists of 15 true-false items. This instrument has been shown to have a test-retest reliability of .83 (Templer, 1970).

\section{Procedure}

All testing took place during regularly scheduled class sessions. Informed-consent forms were completed by all of the subjects prior to the distribution of the questionnaire booklets. No time limit was imposed for the completion of the testing instruments.

\section{RESULTS AND DISCUSSION}

Initial analyses involved comparisons of the entire sample of the men with the entire sample of the women on the four dimensions of major interest: loneliness, optimism, pessimism, and death anxiety. The results of these analyses yielded significance only for the death anxiety factor $[t(259)=2.604, p<.01]$. More specifically, the women had higher death anxiety scores than did the men. This significant difference corroborates a number of previous reports that have shown that women had higher expressed fear of death than did men (e.g., Buzzanga et al., 1989; Davis, Bremer, Anderson, \& Tramill, 1983; Davis, Martin, Wilee, \& Voorhees, 1978; Koob \& Davis, 1977; Sadowski, Davis, \& Loftus-Vergari, 1979; Templer, Lester, \& Ruff, 1974; Tramill, Davis, Bremer, Dudeck, \& Elsbury, 1982; Tramill, Kleinhammer-Tramill, Davis, Parks, \& Alexander, 1984). 
Table 1

Correlations Between Loneliness, Optimism, Pessimism, and Death Anxiety in Male Subjects

\begin{tabular}{lcccc}
\hline \multicolumn{1}{c}{ Factor } & Loneliness & Optimism & Pessimism & $\begin{array}{c}\text { Death } \\
\text { Anxiety }\end{array}$ \\
\hline Loneliness & & $-.41^{*}$ & $.56^{*}$ & .08 \\
Optimism & & $-.53^{*}$ & .09 \\
Pessimism & & & .09 \\
Death Anxiety & & & \\
\hline Note-n $n=93$. & ${ }^{*} p<.01$. & & \\
& & &
\end{tabular}

Table 2

Correlations Between Loneliness, Optimism, Pessimism, and Death Anxiety in Women Subjects

\begin{tabular}{lcccc}
\hline \multicolumn{1}{c}{ Factor } & Loneliness & Optimism & Pessimism & $\begin{array}{c}\text { Death } \\
\text { Anxiety }\end{array}$ \\
\hline Loneliness & & $-.27 \dagger$ & $.32 \dagger$ & $.23 *$ \\
Optimism & & & $-.61 \dagger$ & .04 \\
Pessimism & & & .14 \\
Death Anxiety & & & \\
\hline Note- $n=167$. & ${ }^{*} p<.05 . \quad \dagger p<.01$. &
\end{tabular}

Further analyses involved calculation of the six possible correlations between the four main variables. Table 1 presents the correlations for the men; Table 2 presents the correlations for the women. Generally speaking, a similar pattern of results was shown by both groups of subjects. As predicted, loneliness and optimism were positively related, whereas loneliness and pessimism were negatively related. Reflecting the measurement of opposing attributes, strong negative relationships were shown between optimism and pessimism. These data agree with results supported by Davis et al. (in press).

More surprising was the finding that death anxiety was not strongly related to the other factors under study. Only one such relationship achieved significance. In this instance, it was shown that loneliness and expressed death anxiety were positively related for the women $(r=.23)$. In all cases, optimism and pessimism showed virtually no relationship to death anxiety.

In an attempt to more thoroughly probe these potential relationships, subgroups of men and women who were high $(+1 S D)$ and low $(-1 S D)$ in death anxiety were formed. Subsequent comparisons were made of the loneliness, optimism, and pessimism scores of the high and low subgroups. Since none of the comparisons proved to be significant, it can be concluded that optimism, pessimism, and loneliness simply are not dimensions that discriminate well between men and women who have high and low death anxiety, respectively.

\section{REFERENCES}

Buzzanga, V. L., Miller, H. R., Perne, S. E., Sander, J. A., DAvIS, S. F. (1989). The relationship between death anxiety and level of self-esteem: A reassessment. Bulletin of the Psychonomic Society, 27, 570-572.

Davis, S. F., Bremer, S. A., Anderson, B. J., \& Tramill, J. L. (1983). The interrelationships of ego strength, self-esteem, death anxiety, and gender in undergraduate college students. Journal of General Psychology, 108, 55-59.

Davis, S. F., Hanson, H., Edson, R., \& Ziegler, C. (in press). The relationship between optimism-pessimism, loneliness, and level of selfesteem in college students. College Student Journal.

Davis, S. F., Martin, D. A., Wilee, C. A., \& Voorhees, J. W. (1978). Relationship of fear of death and level of self-esteem in college students. Psychological Reports, 42, 419-422.

Dember, W. N., \& Brooks, J. (1989). A new instrument for measuring optimism and pessimism: Test-retest reliability and relations with happiness and religious commitment. Bulletin of the Psychonomic Society, 27, 365-366.

Dember, W. N., Martin, S. H., Hummer, M. K., Howe, R., \& Melton, R. S. (1989). The measurement of optimism and pessimism. Current Psychology: Research \& Reviews, 8, 102-119.

КоOв, P. B., \& DAvis, S. F. (1977). Fear of death in military officers. Psychological Reports, 40, 261-262.

Russell, D., Peplau, L. A., \& Cutrona, C. E. (1980). The Revised UCLA Loneliness Scale: Concurrent and discriminant validity evidence. Journal of Personality \& Social Psychology, 39, 472-480.

Sadowski, C. J., Davis, S. F., L LofTUS-Vergari, M. C. (1979). Locus of control and death anxiety: A reexamination. Omega, 10, 203-209.

TEMPLER, D. I. (1970). The construction and validation of a death anxiety scale. Journal of General Psychology, 82, 165-177.

TeMPLER, D. I., LeSTER, D., \& RUFF, C. F. (1974). Fear of death and femininity. Psychological Reports, 35, 530.

Tramill, J. L., Davis, S. F., Bremer, S., Dudeck, M. M., \& Elsbury, D. L. (1982). A proposed relationship between the unidimensional short form of the TMAS and the DAS: The effects of embedding vs. separate administration. Bulletin of the Psychonomic Society, 19, 209-211.

Tramill, J. L., Kleinhammer-Tramill, P. J., Davis, S. F., Parks, C. S., \& AleXander, D. (1984). The relationship between the Type A behavior pattern, fear of death, and manifest anxiety. Bulletin of the Psychonomic Society, 22, 42-44.

(Manuscript received September 28, 1991.) 